Davis, K. L., S. M. Karpanty, J. A. Spendelow, J. B. Cohen, M. A. Althouse, K. C. Parsons, C. F. Luttazi, D. H. Catlin, and D. Gibson. 2019. Residency, recruitment, and stopover duration of hatch-year Roseate Terns (Sterna dougallii) during the premigratory staging period. Avian Conservation and Ecology 14(2):11. https://doi.org/10.5751/ACE-01416-140211

Copyright (C) 2019 by the author(s). Published here under license by the Resilience Alliance.

Research Paper

\title{
Residency, recruitment, and stopover duration of hatch-year Roseate Terns (Sterna dougallii) during the premigratory staging period
}

Kayla L. Davis ${ }^{1}$, Sarah M. Karpanty ${ }^{1}$, Jeffrey A. Spendelow ${ }^{2}$,Jonathan B. Cohen ${ }^{3}$, Melissa A. Althouse ${ }^{3}$, Katharine C. Parsons $^{4}$, Cristin F. Luttazi ${ }^{5}$, Daniel H. Catlin ${ }^{1}$ and Daniel Gibson ${ }^{1}$

${ }^{1}$ Department of Fish and Wildlife Conservation, Virginia Tech, Blacksburg, Virginia, USA, ${ }^{2}$ U.S. Geological Survey, Patuxent Wildlife Research Center, Laurel, Maryland, USA, ${ }^{3}$ Department of Environmental and Forest Biology, State University of New York, College of Environmental Science and Forestry, Syracuse, New York, USA, ${ }^{4}$ Coastal Waterbird Program, Mass Audubon, Cummaquid, Massachusetts, USA, ${ }^{5}$ Duxbury Beach Reservation, Duxbury, Massachusetts, USA

\begin{abstract}
Seabird demography and spatial distribution outside of the breeding season are poorly understood, and migratory stopover and staging sites represent important energetic bottlenecks during the avian annual cycle. We quantified hatch-year Roseate Tern (Sterna dougallii) weekly residency, weekly recruitment rate into the staging population, and derived weekly staging population growth rate during two postbreeding, premigratory staging seasons (2014 and 2015) at Cape Cod National Seashore, Massachusetts, USA. We also estimated hatch-year tern stopover duration at Cape Cod staging grounds. Tern residency probability at Cape Cod National Seashore during 2014 and 2015 was nearly 1 during the first weeks of the season and decreased steadily over the last 4 weeks to $\sim 0.5$ in the final week of the study. Recruitment rates into the staging population, representing the weekly per capita change in hatchyear terns present during the staging season, indicated that most terns arrived on the staging grounds during the first weeks of the staging season (16 July to 19 August). We also identified differences in staging duration between birds from the two breeding regions. Hatch-year terns from the southernmost region spent less time staging at Cape Cod National Seashore than their northern counterparts in both 2014 and 2015. These differences may indicate alternative staging strategies for individuals originating in different regions and possibly reveal differences in resource conditions between these areas, for example, in the availability of ephemeral prey fish.
\end{abstract}

\section{Taux de résidence et de recrutement et durée de séjour de jeunes Sternes de Dougall (Sterna dougallii) de l'année pendant la saison de rassemblement pré-migration}

RÉSUMÉ. La démographie et la répartition spatiale des oiseaux marins en dehors de la saison de nidification sont peu connues, et les haltes migratoires représentent d'importants goulots énergétiques durant le cycle annuel des oiseaux. Nous avons quantifié le taux de résidence et de recrutement hebdomadaires de jeunes Sternes de Dougall (Sterna dougallii) de l'année et avons dérivé le taux de croissance hebdomadaire de la population locale durant deux saisons de rassemblement post-nidification et pré-migration d'oiseaux (2014 et 2015) au Cape Cod National Seashore, Massachusetts, États-Unis. Nous avons aussi calculé la durée de séjour des jeunes sternes de l'année aux haltes migratoires de Cape Cod. La probabilité de résidence des sternes au Cape Cod National Seashore en 2014 et 2015 a atteint presque 1 durant les premières semaines de la saison et a chuté de façon continue durant les 4 dernières semaines, pour atteindre $\sim 0,5$ la dernière semaine de l'étude. Le taux de recrutement dans la population des haltes migratoires, représentant le changement hebdomadaire par capita de jeunes de l'année présents durant la saison de rassemblement, a révélé que la plupart des sternes arrivaient sur les haltes migratoires pendant les premières semaines de la saison post-nidification (16 juillet au 19 août). Nous avons aussi observé que la durée de séjour des oiseaux provenant de deux régions de nidification était différente. Les jeunes de l'année issus de la région la plus au sud ont passé moins de temps au Cape Cod National Seashore que celles provenant de régions plus au nord, tant en 2014 qu'en 2015. Ces différences laissent croire que les individus provenant de différentes régions utilisent peut-être des stratégies alternatives de séjour aux haltes migratoires, et qu'il est aussi possible que les ressources de ces deux régions soient différentes, par exemple, en matière de disponibilité de poissons éphémères.

Key Words: recruitment; residency; Roseate Tern; staging; Sterna dougallii

\section{INTRODUCTION}

Seabirds are sentinel species in the marine environment (Cairns 1988, Piatt et al. 2007, Brisson-Curadeau et al. 2017), yet their ecology and distribution during the nonbreeding period is poorly understood (Huettmann and Diamond 2000). This dearth of information is concerning considering that staging, migration, and wintering periods comprise the majority of the avian annual cycle, and conditions during these periods may have carryover effects that influence survival and reproduction in subsequent breeding seasons (Sorensen et al. 2009, Harrison et al. 2011, 
Salton et al. 2015, Szostek and Becker 2015). Additionally, conditions during the breeding season, such as resource competition, may also influence migration strategies (Lamb et al. 2017).

Migratory stopover and staging sites are particularly important because they represent energetic bottlenecks for migratory species (Warnock 2010), and population dynamics at these sites can influence demographic rates during the rest of the year (Baker et al. 2004, Morrissette et al. 2010, Harrison et al. 2011, McGowan et al. 2011). The staging period is particularly important for hatchyear birds (Braasch et al. 2009, Catlin et al. 2014); not only do hatch-year birds need to build fat stores for migration, but they also may continue to grow throughout the staging and migration period (Sedinger 1986, Lesage and Gauthier 1997, Stienen and Brenninkmeijer 2002, Schauroth and Becker 2008, Braasch et al. 2009). Many seabird species exhibit prolonged parental care postfledging (Ashmole and Tovar 1968, Feare 1975, Burger 1980, Limmer and Becker 2009, Watson et al. 2012), and while at staging grounds, offspring may be dependent on caregiving adults (Shealer and Burger 1995, Watson and Hatch 1999) while they continue to grow throughout the staging period. Factors that could potentially impact adults' ability to care for dependent offspring, including availability of ephemeral food resources (Pedro et al. 2014), displacement from optimal foraging sites (Velando and Munilla 2011), or disturbance events (Velando and Munilla 2011), may influence offspring survival on the staging grounds or during migration. Indeed, studies of Common Terns (Sterna hirundo) have shown that postfledging mass can be a determinant of both survival later in life and age of recruitment into the breeding population (Braasch et al. 2009); thus, hatchyear staging condition and its effects on demography may have population-level implications.

We devised a mark-recapture study, focusing specifically on hatchyear Roseate Terns (Sterna dougallii), to look at recruitment, turnover, and duration of residency at a critical staging area because these factors have implications for annual population dynamics. Roseate Terns from the entire northwest Atlantic (NWA) breeding range congregate at and around Cape Cod, Massachusetts, USA, to stage after the breeding season (Trull et al. 1999); thus, events at Cape Cod may impact much of the breeding population. In addition, we sought to identify key times for implementing management actions that could benefit the greatest number of staging Roseate Terns. We present data from two postbreeding, premigratory staging seasons (2014 and 2015) at Cape Cod National Seashore to estimate residency, i.e., the probability that an individual hatch-year Roseate Tern present in one survey period at Cape Cod National Seashore is also present in the next survey period. We expected to see high residency probabilities early in the season because hatch-year terns must spend time being fed by their parents before they can make their first migration to South America. We also estimated recruitment rate, i.e., the per capita change in numbers of hatch-year terns from one survey period to the next, and staging duration, i.e., the time hatch-year Roseate Terns spent staging at Cape Cod National Seashore.

Considered together, these parameters allow us to determine the most important times for hatch-year Roseate Tern staging at Cape Cod National Seashore, including when the most individuals are present there and the most important times for management activities to benefit the largest number of hatch-year terns. The timing of arrival and staging duration for hatch-year terns originating from different colonies may provide indirect evidence for differential migration strategies or resource competition among colonies or colony regions. Our study is the first to formally address Roseate Tern staging demography and may inform management of important bird areas and future studies of tern annual cycle population dynamics.

\section{METHODS}

\section{Study species}

Roseate Terns are an ideal species for studying staging demography because a large proportion of the NWA population stages at or around Cape Cod, Massachusetts, before fall southward migration, and while there, they are readily accessible to researchers (Jedrey et al. 2010, Watson et al. 2012). The NWA population of Roseate Terns was listed as endangered under the Endangered Species Act in 1987 (U.S. Department of the Interior, Fish and Wildlife Service 1987), was listed as threatened in Canada in 1986, and was later updated to endangered in 1999 (Committee on the Status of Endangered Wildlife in Canada 1999). Since listing, this population has been intensively monitored on its breeding grounds (coastal islands from Nova Scotia to New York; Nisbet and Spendelow 1999), but little work has focused on other parts of the annual cycle. Despite intensive management efforts, the Roseate Tern population declined more than $20 \%$ between 2000 and 2008 (Spendelow et al. 2008). After 2008, Roseate Tern numbers initially rebounded slowly, but by 2018, the NWA Roseate Tern population was larger than it had been before the 2000 decline (Roseate Tern Working Group, unpublished data). Adult survival and productivity have remained relatively consistent in years of increasing and declining population trends (Spendelow et al. 2008), suggesting that postfledging survival and recruitment into the breeding population may have driven the decline and recovery (Spendelow et al. 2008). However, few studies have investigated hatch-year Roseate Tern demography (but see Spendelow et al. 2002, Lebreton et al. 2003, Monticelli et al. 2008, Seward et al. 2019), and studies conducted outside of the breeding season are needed for a comprehensive understanding of population dynamics of this species.

\section{Study area}

Cape Cod National Seashore encompasses more than $180 \mathrm{~km}^{2}$ of marine, estuarine, freshwater, and terrestrial ecosystems (Division of Natural Resource and Science, Cape Cod National Seashore 2015). Roseate Terns are typically found in mixed species flocks of mostly Common Terns on the staging grounds, although other species such as Arctic Terns (Sterna paradisaea), Forster's Terns (S. fosteri), and Black Terns (Chlidonias niger) may join these flocks. Although Roseate Terns travel and forage over a wide expanse of water throughout the staging period, they usually congregate to rest in large numbers in only a few places. In past years, Roseate Terns have used roughly $2.4 \mathrm{~km}^{2}$ or less of Cape Cod intertidal areas for loafing during fall staging seasons (E. L. Jedrey, personal communication). We are aware of no other wideranging breeding and wintering endangered bird that is so concentrated in its use of resting habitat during this critical stage in its life cycle. 
The park receives more than 4 million visitors annually with peak recreational activity coinciding with the postbreeding staging period and tern migration (mid-July to late September; Trull et al. 1999). Recreational activities such as walking, hiking, dog walking, bicycling, swimming, water sports, beach sports, beach driving, fishing, and kayaking are common at Cape Cod National Seashore. These activities vary in intensity based on proximity to parking areas and biking and hiking trails and based on management actions designed to protect nesting and staging shorebirds and terns, specifically endangered Roseate Terns. We selected sites within Cape Cod National Seashore based on preliminary field observations indicating significant and consistent Roseate Tern use within and across seasons (Fig. 1; Trull et al. 1999, Jedrey et al. 2010). Other coastal areas in Massachusetts (e.g., the islands from Nantucket to Martha's Vineyard that form the southern boundary of Nantucket Sound), Rhode Island, and eastern Long Island are also known Roseate Tern staging sites (Trull et al. 1999, Watson and Hatch 1999); however, logistical constraints prevented us from regularly surveying these other staging areas.

Fig. 1. Cape Cod National Seashore, Massachusetts, boundaries and the survey sites visited during the 2014 and 2015 Roseate Tern (Sterna dougallii) staging seasons. The inset figure shows Roseate Tern colony sites active (one or more Roseate Tern nests present; from northeast to southwest: Country Island, Nova Scotia; North Brother Island, Nova Scotia; Eastern Egg Rock, Maine; Jenny Island, Maine; Stratton Island, Maine; Seavey Island, New Hampshire; Monomoy National Wildlife Refuge, Massachusetts; Buzzards Bay, Massachusetts [this site did not participate in Roseate Tern banding]; Great Gull Island, New York; and Falkner Island, Connecticut) during the 2014 and 2015 breeding seasons.

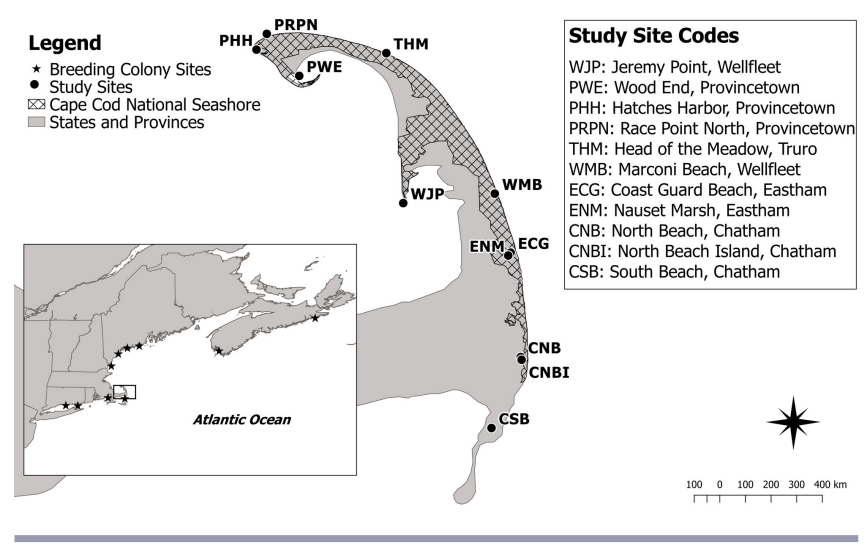

\section{Field methods}

During the 2014 and 2015 breeding seasons, colony managers at nine Roseate Tern colony sites (from northeast to southwest: Country Island, Nova Scotia; The Brothers Island, Nova Scotia; Eastern Egg Rock, Maine; Jenny Island, Maine; Stratton Island, Maine; Seavey Island, New Hampshire; Monomoy National Wildlife Refuge, Massachusetts; Great Gull Island, New York; and Falkner Island, Connecticut; Fig. 1) banded Roseate Tern chicks with uniquely coded, plastic, field-readable leg bands. The banding protocol varied among colonies by age at banding (days posthatch) and band application method (e.g., leg banded, type of glue used to close bands, etc.), but variations in methods among colony sites were minor. We do not include any capture or resighting events from the breeding colonies in our analyses. Our data begin with the initial observation of each hatch-year Roseate Tern at the Cape Cod staging grounds.

During the staging period at Cape Cod National Seashore, all observers used spotting scopes to identify uniquely banded hatchyear Roseate Terns. Flock observation surveys consisted of flock scans for band resighting. The flock observation surveys varied in length depending on the number of birds in staging flocks and the number of banded terns present but generally were conducted in 2-h time blocks. We separated flock observation surveys into 2-h blocks to record environmental variables that were used as covariates for other analyses we have not described, including tidal stage, wind speed, cloud cover, and visibility, because these variables were likely to change within a 2-h window. We terminated a survey when we had resighted all banded Roseate Terns, very few new (unrecorded) banded Roseate Terns entered a site, or resighting conditions became unfavorable because of poor lighting, weather, or an incoming tide. Average flock observation survey length was approximately $1.5 \mathrm{~h}$, and each observer $(n=10)$ conducted between 1 and 4 surveys each day at 1 to 3 study sites $(n=11)$. We surveyed all study sites (except South Beach, Chatham, which required special transport from the U.S. Fish and Wildlife Service to visit) at least once every 2-3 d. Our sampling occasions for the mark-recapture analysis were 7-d periods; thus, we sampled all study sites at least once (usually 2-7 times) during each sampling occasion.

\section{Analytical methods}

We used the R (R Development Core Team 2008) package RMark (Laake 2013) to fit the Pradel model parameterization for survival and recruitment (Pradel 1996) of banded hatch-year Roseate Terns in the program MARK (v. 6.1; White and Burnham 1999). We estimated weekly (7-d period) detection probability $(p)$, residency $(\Phi)$, and recruitment rate $(f)$ and derived lambda (population growth rate parameter; $\lambda$ ) by week for hatch-year Roseate Terns staging at Cape Cod National Seashore during the 2014 and 2015 staging seasons, where year and colony region of origin (northern region: Nova Scotia, Maine, and New Hampshire; and southern region: New York, Connecticut, and Massachusetts; henceforth region) were included as categorical variables. The Pradel model uses a standard-time and a reversetime capture-recapture approach to estimate survival (residency) and seniority (or recruitment), respectively. We used this parameterization because it models per capita recruitment directly, rather than deriving it from other estimated parameters, which allowed us to model the recruitment parameter as a function of covariates. Because we did not record the ratio of marked to unmarked birds present during each survey, the interpretation of recruitment in our models is the per capita change (increase/decrease) in banded terns present at time (week) $t+1$ relative to the banded terns present at time $t$.

We tested a subset of 13 model parameterizations, including interactive and additive effects of time and categorical variables (year and region) and linear and quadratic effects on time, on each of the three model parameters $(p, \Phi$, and $f$ ). Each of the different model parameterizations represented a hypothesis about the 
potential factors (time, year, and region) influencing banded hatch-year Roseate Tern arrival to and residency at the Cape Cod staging grounds. We tested both linear and quadratic effects of time (week of season) on the model parameters because we suspected that recruitment may reach an asymptotic minimum at some point during the staging season, and we expected that residency may exponentially decline near the end of the season. We fitted a series of models for each parameter, beginning with the detection probability $(p)$, while we used the most general parameterization (year $\times$ region $\times$ week varying) for the other model parameters ( $\Phi$ and $f$ ). To estimate all $\Phi$ and $f$ parameters in our time-varying models, we constrained the detection probability such that our first two and final two detection probabilities were equal (i.e., $p 1=p 2$ and $p 9=p 10$ ). We ranked models using information-theoretic-based Akaike's information criterion (AIC; Burnham and Anderson 2002). We measured goodness-of-fit of the general model (year $\times$ region $\times$ week varying) using the program RELEASE extension in the program MARK on the forward and reversed capture histories to test for extrabinomial variation in residency and recruitment, respectively. We then adjusted $\hat{c}$ based on the highest estimate obtained from the RELEASE tests and used the adjusted AIC (QAIC) to rank our models. We repeated this model selection procedure using the best-supported models from previous steps to fit models for the remaining parameters ( $\Phi$ and $f$ ). See Appendix 1 for the full model list and rankings.

We used the program SODA (Schaub et al. 2001), which uses a bootstrapping technique, to calculate mean stopover duration and its precision under our selected model for immigration and emigration. The program SODA calculates total staging duration by estimating the number of weeks present before encounter (seniority in the program SODA, recruitment in the Pradel model) and the number of weeks present after encounter (survival in the program SODA, residency in the Pradel model). However, SODA does not allow for model comparison, so we determined the survival and seniority parameterization using the best-supported model from our Pradel model analysis. We modeled time-varying detection probability, and we constrained our first two and final two $p$ parameters to be equal to estimate time variation in all model parameters and to be consistent with our Pradel model parameterization described previously. We also modeled a linear time trend on survival and time-varying seniority based on our Pradel model results for residency and recruitment. The best model from our Pradel analysis included a quadratic time trend on residency probability, and we were unable to fit this parameterization in the program SODA; thus, we modeled the closest approximation, a linear time trend. We obtained estimates of stopover duration for each unique region-year combination (resulting in four SODA model runs). We used the ggplot2 package (Wickham 2009) to plot results.

\section{RESULTS}

We observed 1630 uniquely identifiable hatch-year Roseate Terns between the 2 staging seasons at Cape Cod National Seashore (754 hatch-year Roseate Terns in 2014 and 876 hatch-years in 2015). We applied the $\hat{c}$ value of 2.03 to the Pradel model to account for overdispersion of the data. Our top model for residency and recruitment $\left(\Phi_{\text {Time }} p_{\text {time } \times \text { year }+ \text { region }} f_{\text {time }+ \text { year }+ \text { region }}\right)$ constrained residency $(\Phi)$ to follow a quadratic trend over the staging period, detection probability $(p)$ to vary by week differently between years and additively between regions, and recruitment $(f)$ to vary by week additively between years and regions (Appendix 1). Residency probability was consistently high $(97-93 \%)$ between the 1 st and 6th wk of the studied staging period (16 July-26 August); residency dropped slightly below 90\% between the 6th and 7th wk (20-26 August and 27 August-2 September) and continued to decrease through the final week of the study period when residency probability was 49\% (17 September-24 September; Fig. 2A). Weekly recruitment into the staging population, or the per capita change in banded hatch-year Roseate Terns per week of the staging season, was highest between weeks 1 (16-22 July) and 2 (23-29 July) and decreased steadily until the third survey period between weeks 3 (30 July-5 August) and 4 (6-12 August), when recruitment rate was nearly zero (Fig. 2B). A similar pattern was reflected in the population growth parameter, lambda (Fig. 2C; plotted as $\log (\lambda)$, or $r$, the instantaneous growth rate). The banded hatch-year Roseate Tern staging population increased between week 1 (16-22 July) and week 6 (20-26 August) for all region-year combinations except the southern region in 2015, which continued to increase slightly between week 6 (20-26 August) and week 7 (27 August-2 September).

We defined model structures for residency, seniority, and detection probabilities for the SODA analyses based on the bestsupported model from our Pradel analysis as described previously. We observed a curvilinear trend in staging duration by week; hatch-year Roseate Terns present at the beginning and end of the staging season were more likely to be present on the staging grounds for longer than hatch-year terns present during the middle of the staging season on average (Fig. 3). We also identified differences in staging duration between birds from the two breeding regions. Hatch-year terns from the southernmost breeding colony sites spent less time staging at Cape Cod National Seashore than their northern counterparts in both 2014 and 2015. In 2014, differences in staging duration between the regions were restricted to the first $2 \mathrm{wk}$ of the study period; however, staging duration differences between regions were more pronounced and consistent across weeks in 2015 (Fig. 3).

\section{DISCUSSION}

We present data from two postbreeding, premigratory staging seasons (2014 and 2015) at Cape Cod National Seashore, Massachusetts, USA, to estimate residency, i.e., the probability that an individual hatch-year Roseate Tern present in one survey period at Cape Cod National Seashore is also present in the next survey period; recruitment rate, i.e., the per capita change in numbers of banded hatch-year terns from one survey period to the next; and staging duration, i.e., the time hatch-year Roseate Terns spent staging at Cape Cod National Seashore. We were interested in quantifying these parameters because staging and migration is an understudied period of the avian annual cycle (Faaborg et al. 2010), especially for seabirds and hatch-year birds (Huettmann and Diamond 2000), and conditions during staging periods may influence population dynamics as much as conditions at breeding sites (Baker et al. 2004, Morrissette et al. 2010, McGowan et al. 2011). Quantifying staging residency, recruitment, and duration allows us to determine the most important times for hatch-year Roseate Terns staging at Cape Cod 
Fig. 2. (A) Estimates of apparent residency rate $(\Phi)$ from the best-supported model, $\Phi_{(\text {Time })} p_{\text {(time } \times \text { year }+ \text { region })} f_{\text {(time }+ \text { year }+ \text { region })}$. (B) Estimates of recruitment rate $(f)$, the per capita increase in hatch-year Roseate Terns (Sterna dougallii) at each sampling interval (7-d periods), from the best-supported model. (C) Derived estimates of the log of lambda $(\lambda)$, the instantaneous rate of growth $(r)$, for hatch-year Roseate Terns staging at Cape Cod National Seashore during the postbreeding, premigratory staging period (16 July [week 1] to 24 September [week 10]) in 2014 and 2015. The dashed line represents $r=0$. Values above the dashed line indicate an increasing staging population trend, and values below the dashed line indicate a declining staging population trend. In panels $\mathrm{B}$ and $\mathrm{C}$, orange shades indicate estimates for terns from the northern colony region (Nova Scotia to New Hampshire colonies), and purple shades indicate estimates for terns from the southern colony region (Massachusetts to Connecticut colonies). Dark tones indicate estimates for the 2014 staging season, and pastel tones indicate estimates for the 2015 staging season. All estimates were obtained from Pradel model parameterization for survival and recruitment in the $\mathrm{R}$ ( $\mathrm{R}$ Development Core Team 2008) package RMark (Laake 2013). All error bars indicate 95\% confidence intervals.
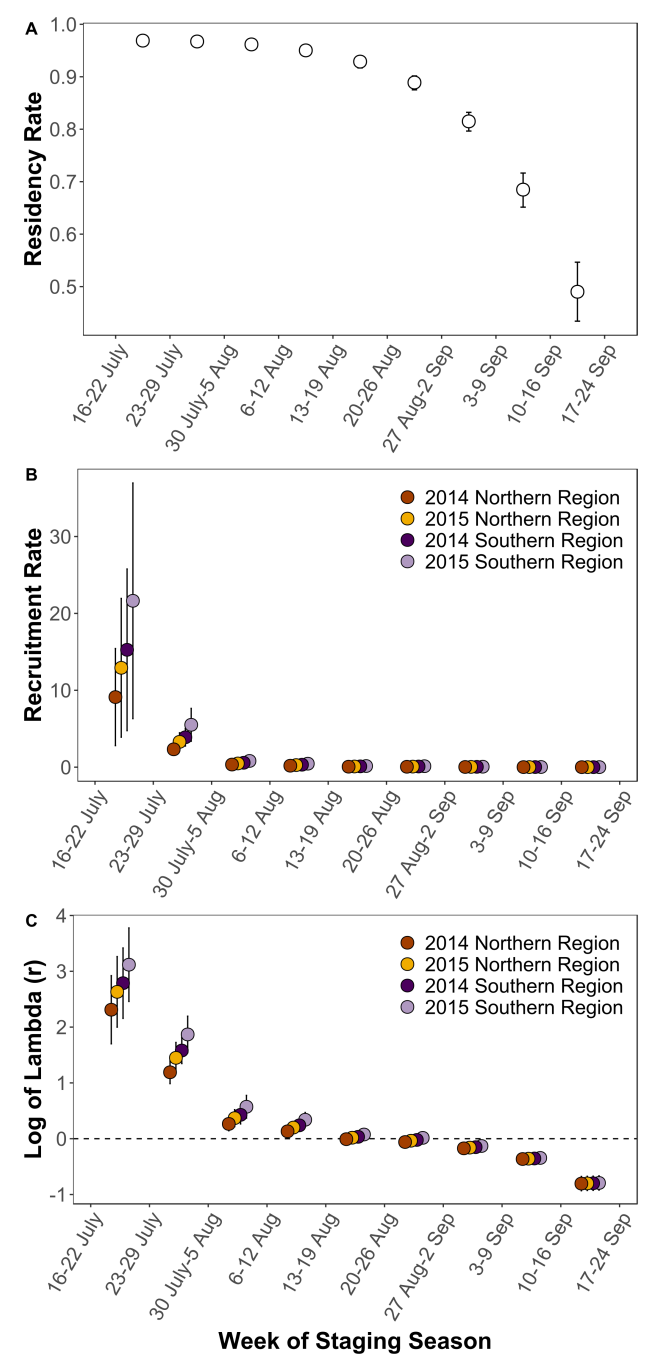

Fig. 3. Estimates of staging duration (weeks) for hatch-year Roseate Terns (Sterna dougallii) from the two colony regions (northern region: Country Island, Nova Scotia; The Brothers Island, Nova Scotia; Eastern Egg Rock, Maine; Jenny Island, Maine; Stratton Island, Maine; and Seavey Island, New Hampshire; and southern region: Monomoy National Wildlife Refuge, Massachusetts; Great Gull Island, New York; and Falkner Island, Connecticut) during two staging seasons (2014 and 2015) at Cape Cod National Seashore (CCNS). Orange shades indicate estimates for terns from the northern colony region, and purple shades indicate estimates for terns from the southern colony region. Dark tones indicate estimates for the 2014 staging season, and pastel tones indicate estimates for the 2015 staging season. Staging duration estimates were obtained using the program SODA (Schaub et al. 2001), and model parameterizations were based on results from our Pradel analysis of recruitment and residency. Error bars are 95\% confidence intervals.

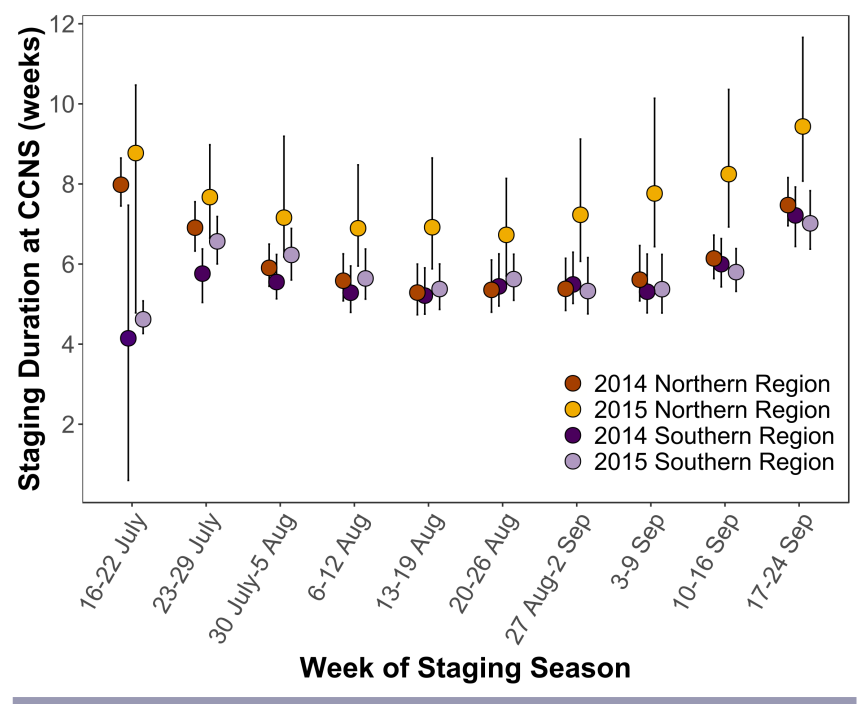

National Seashore, including when the greatest numbers of individuals are present there and the most important times for management activities to benefit the largest number of hatch-year terns. Additionally, by identifying peak times of Roseate Tern staging activity, we may be able to infer times and locations of prey fish or other resource availability at Cape Cod and possible resource limitation at colony sites.

Weekly residency during the first weeks of the staging period at Cape Cod National Seashore during the 2014 and 2015 seasons was nearly 1 , and we did not see substantial decreases in residency rates until the latter weeks of the staging period. We attribute the late-season decrease in residency rates to permanent emigration from the Cape Cod staging grounds as a result of departure for fall migration. Although, we note that in our models mortality is confounded with permanent emigration; thus, there is some unknown contribution of mortality to our apparent residency rate estimates (Williams et al. 2002). These results are what we expected to see given that hatch-year terns are dependent on their caregiving parent while at the staging grounds, and fat acquisition at this time may be critically important for survival of their first 
long-distance migration to South America. In contrast to the other parameters that we estimated, residency rate did not vary by year or colony region of origin. This indicates that regardless of where they came from, hatch-year Roseate Terns tended to depart the Cape Cod staging grounds (permanently) around the same time, and this was similar across both years of our study. Additionally, our results for timing of departure are consistent with previous findings for Common Terns at the Cape Cod staging grounds (Nisbet et al. 2011, Loring et al. 2017). Together, these results suggest that some exogenous force, such as environmental conditions, day length, and so forth, may mediate the timing of tern migration in this area.

In addition to residency, we quantified recruitment rates, which showed the per capita change in banded hatch-year Roseate Terns present during each week of the staging season. When considered with the results for residency, which showed that residency probability declined after week 6 of the staging season, recruitment results indicated that most hatch-year Roseate Terns were present on the Cape Cod National Seashore staging grounds during the first 3-5 wk of the season. Moreover, our results for $\lambda$ indicated that the staging population increased during the first 5 wk (16 July-19 August) of the staging season, with the highest rates of staging population growth occurring during the first 3 wk (16 July-5 August; Fig. 2C). We found that recruitment and population growth rate varied by colony region and year, which may indicate different staging strategies, including variation in arrival times, between birds from different colony regions and across years.

Hatch-year Roseate Terns present at the beginning or the end of the staging season were most likely to spend the longest amount of time staging at Cape Cod National Seashore. The SODA method uses a gliding average to calculate staging duration before an individual is first resighted and after an individual is last resighted (Schaub et al. 2001: Eq. 1). This gliding average is most influential in the first and last sampling periods (Schaub et al. 2001) because the tails of the sampling period have the least amount of data available to estimate staging duration before and after an individual is first and last resighted, respectively. Thus, the uncertainty is largest around the estimates of staging duration at the tails of the sampling period. Therefore, the curvilinear trend observed in staging duration may be an artifact of variance introduced by the gliding average of the first seniority parameters and last survival parameters on the estimates of staging duration at the beginning and end of the study period, respectively.

Nonetheless, given that most birds arrived on the staging grounds during the first $2 \mathrm{wk}$ of the study period, the long staging durations predicted at the tails of the study period suggest that terns present at the end also were most likely present at the beginning of the study period. This suggests that terns present after the pulse of entrants may have had a shorter staging duration on average than terns present at the beginning and end of the study period. This could simply be attributed to the fact that terns arriving late have fewer weeks left to be present at the staging grounds relative to those that arrived earlier. Thus, differences in staging durations could be driven by differential arrival times to the staging grounds. In addition, differences in premigratory condition between terns arriving earlier versus those arriving later in the staging season or potential resource limitations at the staging grounds (Ke et al.
2019), such as loafing area, access to foraging grounds, prey abundance, or competition with Common Terns (Duffy 1986) and kleptoparasitic gulls (Althouse et al. 2019), could mediate hatchyear tern staging duration at Cape Cod. Additional work is needed to investigate hatch-year Roseate Tern condition while on the Cape Cod National Seashore staging grounds, as well as tern habitat use versus availability and interspecies interactions, to determine if this hypothesis is valid; however, we know that Roseate Terns are relatively concentrated in their use of Cape Cod National Seashore staging areas (Trull et al. 1999), which lends some support to this idea of staging habitat limitation.

We also found differences in staging duration between hatch-year Roseate Terns from the different breeding regions, although these differences were more pronounced in 2015 than in 2014. This result may indicate slight differences in migration strategies within the NWA population. Taken together with the residency, recruitment, and population growth rate parameters, these results suggest that differences in staging duration between the two regions may be driven by differences in arrival time to the staging grounds. As noted previously, regardless of region of origin, hatch-year terns departed from the staging grounds around the same time on average; however, there were differences in recruitment and population growth rates between the breeding regions. These rate differences support the hypothesis that terns from the northern region arrived earlier and in higher numbers than terns from the southern breeding region. Birds from the southern breeding colonies may remain at their breeding sites to stage or utilize areas outside of Cape Cod National Seashore during the staging period. Indeed, it is likely that Roseate Terns use eastern Long Island, Rhode Island, and the NantucketMuskeget Shoals areas as staging grounds in addition to, or instead of, Cape Cod National Seashore (Spendelow, Ernst, Neal, et al., unpublished data). Terns frequently move among staging sites within Cape Cod National Seashore, sometimes traveling more than $40 \mathrm{~km}$ in a single day (J. A. Spendelow, personal observation). Therefore, it is likely that terns also travel between Cape Cod and the surrounding areas as well.

Although we are confident that our study period encompassed most of the staging period, we cannot be certain that we witnessed the end of staging. We observed the influx of hatch-year Roseate Terns to Cape Cod National Seashore at the beginning of the staging season as we began surveys approximately $3 \mathrm{wk}$ before we observed the first hatch-year tern in both 2014 and 2015; however, as shown by our estimates for residency rates, many terns were still present at Cape Cod National Seashore when our study period ended. Thus, our estimates are likely minimum values for staging duration because we did not observe complete emigration from Cape Cod National Seashore in either year.

Our results indicate the peak time of Roseate Tern staging at Cape Cod National Seashore, and they also may provide evidence for and timing of resource competition and/or prey depletion at breeding colonies. For seabird species, staging areas may offer an escape from density-dependent competition for food resources at breeding colonies (Lewis et al. 2001). Indeed, Ashmole's (1963) halo hypothesis postulates that predation by seabirds at large, tropical colonies depletes prey resources surrounding the colony, forcing seabirds to travel farther to forage successfully, and this may be true in temperate and polar climates as well (Birt et al. 
1987, Ainley et al. 2004, 2006). By the end of the breeding season, prey resources at colony sites may be depleted enough that the costs of long foraging trips may be outweighed by the benefits of leaving the colony for a richer foraging area. For seabirds such as terns that deliver whole fish to their offspring rather than regurgitating fish meals (Davis et al. 2019), the cost of traveling long distances to forage and deliver food to their young may partially mediate the staging strategy that we observe in Roseate Terns (and Common Terns; Gaston et al. 2007). Birds from the northern region may move south to the Cape Cod area sooner and in higher numbers than birds from the southern region because of the reduction in availability of ephemeral food resources in the cold-water northern sites. Loring et al. (2017) also found that Common Tern departure from the northern region (Nova Scotia colony sites) was significantly earlier than departure from Monomoy Island, a colony site in the southern region. Bird migration routes and phenology have evolved to occur concurrently with peak periods of resource availability (Stenseth and Mysterud 2002); thus, Roseate and Common Terns from the northern part of the NWA range may become food limited earlier than those from the southern region and therefore spend more time staging at Cape Cod National Seashore than their southern counterparts. Additional work is needed to assess prey fish availability at colony sites throughout the breeding season and at Cape Cod staging areas to determine whether this hypothesis has support. Previous work in Brown Pelicans (Pelecanus occidentalis) has shown that density-dependent resource competition at breeding colonies can influence migratory behavior postbreeding (Lamb et al. 2017).

Based on our results for staging duration and residency rates, we determined that the highest numbers of hatch-year Roseate Terns likely are present at Cape Cod National Seashore between 23 July and 2 September. Management actions meant to protect staging Roseate Terns would be most effective during this window. Although our results indicated high hatch-year residency rates during our study, especially during the first half of our study period, a large proportion of NWA Roseate Terns are concentrated into a few small resting areas during the staging season at Cape Cod National Seashore making them vulnerable to any disturbance events, both natural and anthropogenic, that may occur during this window. Events occurring during migration and staging, particularly strong storms and hurricanes, which are predicted to increase in frequency and intensity in northern and mid-Atlantic latitudes (Tamarin-Brodsky and Kaspi 2017), have the potential to impact the majority of the NWA Roseate Tern population and have major population-level effects (Nisbet and Spendelow 1999, Spendelow et al. 2002).

The period that Roseate Terns spend staging at Cape Cod National Seashore each year is only a short portion of their life spans, but conditions at staging areas and staging season demography play an important role in the annual cycles of these and other bird species (Baker et al. 2004, Morrissette et al. 2010, McGowan et al. 2011). More studies are needed to connect conditions across seasons, i.e., during breeding, fall migration, wintering, and spring migration, to better understand the contributions of each of these periods to avian population dynamics (Faaborg et al. 2010, Harrison et al. 2011). Our study seeks to fill gaps in knowledge about an understudied age class and period of the annual cycle for an endangered seabird, and our results may be used to inform management of important bird areas and future studies of tern annual cycle population dynamics.

Responses to this article can be read online at: http://www.ace-eco.org/issues/responses.php/1416

\section{Acknowledgments:}

We would like to thank the USNPS's Cape Cod National Seashore via the Southeastern Cooperative Ecosystem Studies Unit, the Virginia Tech Department of Fish and Wildlife Conservation, the Virginia Tech Graduate School, and the USGS Patuxent Wildlife Research Center for funding and other logistical support. Our collaborative research at CCNS was performed under permits CACO-2014-SCI-0007, -0015, -0019, and -0020. All banding of Roseate Terns by other partners was done under appropriate federal and state permits and with the approval of the USGS-PWRC Animal Care and Use Committee. All applicable ethical guidelines for the use of birds in research have been followed, including those presented in the Ornithological Council's "Guidelines to the Use of Wild Birds in Research." The use of trade, product, or firm names in this publication is for descriptive purposes only and does not imply endorsement by the U.S. government. We acknowledge S. Brady, J. Correia, C. Egan, L. Evans, L. Gallo, D. Hollie, W. Kennerley, C. King, J. May, A. McBride, M. Sisko, M. Verhoeven, and B. Wilkinson for their tireless effort in collecting the dat a for this work. We thank J. McKnight, P. Shannon, D. Hayward, M. Hayward, K. Iaquinto, H. Hays, G. Cormons, K. Vagos, and their technicians and volunteers for work at colony sites to band and resight Roseate Tern chicks, fledglings, and adults before their departure to the staging grounds. We would like to thank J. D. Nichols and the anonymous reviewers whose helpful comments improved our manuscript.

\section{LITERATURE CITED}

Ainley, D. G., G. Ballard, and K. M. Dugger. 2006. Competition among penguins and cetaceans reveals trophic cascades in the western Ross Sea, Antarctica. Ecology 87:2080-2093. https://doi. org/10.1890/0012-9658(2006)87[2080:CAPACR]2.0.CO;2

Ainley, D. G., C. A. Ribic, G. Ballard, S. Heath, I. Gaffney, B. J. Carl, K. J. Barton, P. R. Wilson, and S. Webb. 2004. Geographic structure of Adélie Penguin populations: overlap in colonyspecific foraging areas. Ecological Monographs 74:159-178. https://doi.org/10.1890/02-4073

Althouse, M. A., J. B. Cohen, S. M. Karpanty, J. A. Spendelow, K. L. Davis, K. C. Parsons, and C. F. Luttazi. 2019. Evaluating response distances to develop buffer zones for staging terns. Journal of Wildlife Management 83:260-271. https://doi. org/10.1002/jwmg.21594

Ashmole, N. P. 1963. The regulation of numbers of tropical oceanic birds. Ibis 103b:458-473. https://doi.org/10.1111/ j.1474-919X.1963.tb06766.x

Ashmole, N. P., and H. Tovar S. 1968. Prolonged parental care in Royal Terns and other birds. Auk 85:90-100. https://doi. org/10.2307/4083627 
Baker, A. J., P. M. Gonzalez, T. Piersma, L. J. Niles, I. de Lima Serrano do Nascimento, P. W. Atkinson, N. A. Clark, C. D. T. Minton, M. K. Peck, and G. Aarts. 2004. Rapid population decline in Red Knots: fitness consequences of decreased refuelling rates and late arrival in Delaware Bay. Proceedings of the Royal Society B: Biological Sciences 271:875-882. https://doi. org/10.1098/rspb.2003.2663

Birt, V. L., T. P. Birt, D. Goulet, D. K. Cairns, and W. A. Montevecchi. 1987. Ashmole's halo: direct evidence of prey depletion by a seabird. Marine Ecology Progress Series 40:205-208. https://doi.org/10.3354/meps040205

Braasch, A., C. Schauroth, and P. H. Becker. 2009. Post-fledging body mass as a determinant of subadult survival in Common Terns Sterna hirundo. Journal of Ornithology 150:401-407. https:// doi.org/10.1007/s10336-008-0362-2

Brisson-Curadeau, E., A. Patterson, S. Whelan, T. Lazarus, and K. H. Elliott. 2017. Tracking Cairns: biologging improves the use of seabirds as sentinels of the sea. Frontiers in Marine Science 4:357. https://doi.org/10.3389/fmars.2017.00357

Burger, J. 1980. The transition to independence and postfledging parental care in seabirds. Pages 367-447 in J. Burger, B. L. Olla, and H. E. Winn, editors. Behavior of marine animals. Plenum, New York, New York, USA. https://doi.org/10.1007/978-1-4684-2988-6_10

Burnham, K. P., and D. R. Anderson. 2002. Model selection and multimodel inference: a practical information-theoretic approach. Springer-Verlag, New York, New York, USA.

Cairns, D. K. 1988. Seabirds as indicators of marine food supplies. Biological Oceanography 5:261-271.

Catlin, D. H., O. Milenkaya, K. L. Hunt, M. J. Friedrich, and J. D. Fraser. 2014. Can river management improve the Piping Plover's long-term survival on the Missouri River? Biological Conservation 180:196-205. https://doi.org/10.1016/j.biocon.2014.10.004

Committee on the Status of Endangered Wildlife in Canada (COSEWIC). 1999. COSEWIC assessment and update status report on the Roseate Tern Sterna dougallii in Canada. COSEWIC, Ottawa, Ontario, Canada. [online] URL: https://wildlife-species. canada.ca/species-risk-registry/document/default_e.cfm? documentID $=1158$

Davis, K. L., S. M. Karpanty, J. A. Spendelow, J. B. Cohen, M. A. Althouse, K. C. Parsons, and C. F. Luttazi. 2019. Begging behavior as an honest signal of need and parent-offspring association during the postfledging dependency period. Ecology and Evolution 9:7497-7508. https://doi.org/10.1002/ece3.5279

Division of Natural Resource and Science, Cape Cod National Seashore. 2015. Shorebird monitoring and management: Cape Cod National Seashore. National Park Service, Washington, D.C., USA. [online] URL: https:/www.nps.gov/caco/learn/nature/ upload/2015_Waterbird_Report_20170829-508-Signed-FIN-pdf. pdf

Duffy, D. C. 1986. Foraging at patches: interactions between Common and Roseate Terns. Ornis Scandinavica (Scandinavian Journal of Ornithology) 17:47-52. https://doi.org/10.2307/3676752
Faaborg, J., R. T. Holmes, A. D. Anders, K. L. Bildstein, K. M. Dugger, S. A. Gauthreaux, Jr., P. Heglund, K. A. Hobson, A. E. Jahn, D. H. Johnson, S. C. Latta, D. J. Levey, P. P. Marra, C. L. Merkord, E. Nol, S. I. Rothstein, T. W. Sherry, T. S. Sillett, F. R. Thompson, III, and N. Warnock. 2010. Conserving migratory land birds in the New World: do we know enough? Ecological Applications 20:398-418. https://doi.org/10.1890/09-0397.1

Feare, C. J. 1975. Post-fledging parental care in Crested and Sooty Terns. Condor 77:368-370. https://doi.org/10.2307/1366255

Gaston, A. J., R. C. Ydenberg, and G. E. J. Smith. 2007. Ashmole's halo and population regulation in seabirds. Marine Ornithology 35:119-126.

Harrison, X. A., J. D. Blount, R. Inger, D. R. Norris, and S. Bearhop. 2011. Carry-over effects as drivers of fitness differences in animals. Journal of Animal Ecology 80:4-18. https://doi. org/10.1111/j.1365-2656.2010.01740.x

Huettmann, F., and A. W. Diamond. 2000. Seabird migration in the Canadian northwest Atlantic Ocean: moulting locations and movement patterns of immature birds. Canadian Journal of Zoology 78:624-647. https://doi.org/10.1139/z99-239

Jedrey, E. L., R. J. Harris, and E. A. Ray. 2010. Roseate Ternscitizens of the world: the Canada to Cape Cod connection. Bird Observer 38:146-150.

Ke, W.-J., P. He, H.-B. Peng, C.-Y. Choi, S.-D. Zhang, D. S. Melville, and Z. Ma. 2019. Migration timing influences the responses of birds to food shortage at their refueling site. Ibis, in press. https://doi.org/10.1111/ibi.12736

Laake, J. L. 2013. RMark: an R interface for analysis of capturerecapture data with MARK. AFSC Processed Report 2013-01. Alaska Fisheries Science Center, National Oceanic and Atmospheric Administration, National Marine Fisheries Service, Seattle, Washington, USA. [online] URL: https://www.afsc.noaa. gov/Publications/ProcRpt/PR2013-01.pdf

Lamb, J. S., Y. G. Satgé, and P. G. R. Jodice. 2017. Influence of density-dependent competition on foraging and migratory behavior of a subtropical colonial seabird. Ecology and Evolution 7:6469-6481. https://doi.org/10.1002/ece3.3216

Lebreton, J. D., J. E. Hines, R. Pradel, J. D. Nichols, and J. A. Spendelow. 2003. Estimation by capture-recapture of recruitment and dispersal over several sites. Oikos 101:253-264. https://doi. org/10.1034/j.1600-0706.2003.11848.x

Lesage, L., and G. Gauthier. 1997. Growth and organ development in Greater Snow Goose goslings. Auk 114:229-241. https://doi.org/10.2307/4089164

Lewis, S., T. N. Sherratt, K. C. Hamer, and S. Wanless. 2001. Evidence of intra-specific competition for food in a pelagic seabird. Nature 412:816-819. https://doi.org/10.1038/35090566

Limmer, B., and P. H. Becker. 2009. Improvement in chick provisioning with parental experience in a seabird. Animal Behaviour 77:1095-1101. https://doi.org/10.1016/j.anbehav.2009.01.015

Loring, P. H., R. A. Ronconi, L. J. Welch, P. D. Taylor, and M. L. Mallory. 2017. Postbreeding dispersal and staging of Common and Arctic Terns throughout the western North Atlantic. Avian 
Conservation and Ecology 12(2):20. https://doi.org/10.5751/ ACE-01086-120220

McGowan, C. P., J. E. Hines, J. D. Nichols, J. E. Lyons, D. R. Smith, K. S. Kalasz, L. J. Niles, A. D. Dey, N. A. Clark, P. W. Atkinson, C. D. T. Minton, and W. Kendall. 2011. Demographic consequences of migratory stopover: linking Red Knot survival to horseshoe crab spawning abundance. Ecosphere 2:1-22. https:// doi.org/10.1890/ES11-00106.1

Monticelli, D., J. A. Ramos, J. E. Hines, J. D. Nichols, and J. A. Spendelow. 2008. Juvenile survival in a tropical population of Roseate Terns: interannual variation and effect of tick parasitism. Marine Ecology Progress Series 365:277-287. https://doi. org/10.3354/meps07508

Morrissette, M., J. Bêty, G. Gauthier, A. Reed, and J. Lefebvre. 2010. Climate, trophic interactions, density dependence and carry-over effects on the population productivity of a migratory Arctic herbivorous bird. Oikos 119:1181-1191. https://doi. org/10.1111/j.1600-0706.2009.18079.x

Nisbet, I. C. T., C. S. Mostello, R. R. Veit, J. W. Fox, and V. Afanasyev. 2011. Migrations and winter quarters of five Common Terns tracked using geolocators. Waterbirds 34:32-39. https://doi. org/10.1675/063.034.0104

Nisbet, I. C. T., and J. A. Spendelow. 1999. Contribution of research to management and recovery of the Roseate Tern: review of a twelve-year project. Waterbirds 22:239-252. https://doi. org/10.2307/1522212

Pedro, P. I., D. Monticelli, V. H. Paiva, and J. A. Ramos. 2014. Diet of tropical Roseate Tern chicks on Aride Island and the role of local oceanographic conditions and age of chicks on food provisioning. Emu 114:146-153. https://doi.org/10.1071/MU13024

Piatt, J. F., A. M. A. Harding, M. Shultz, S. G. Speckman, T. I. van Pelt, G. S. Drew, and A. B. Kettle. 2007. Seabirds as indicators of marine food supplies: Cairns revisited. Marine Ecology Progress Series 352:221-234. https://doi.org/10.3354/meps07078

Pradel, R. 1996. Utilization of capture-mark-recapture for the study of recruitment and population growth rate. Biometrics 52:703-709. https://doi.org/10.2307/2532908

R Development Core Team. 2008. R: a language and environment for statistical computing. R Foundation for Statistical Computing, Vienna, Austria. [online] URL: http://www.R-project.org

Salton, M., C. Saraux, P. Dann, and A. Chiaradia. 2015. Carryover body mass effect from winter to breeding in a resident seabird, the little penguin. Royal Society Open Science 2:140390. https:// doi.org/10.1098/rsos. 140390

Schaub, M., R. Pradel, L. Jenni, and J. D. Lebreton. 2001. Migrating birds stop over longer than usually thought: an improved capture-recapture analysis. Ecology 82:852-859. https://doi.org/10.1890/0012-9658(2001)082[0852:MBSOLT]2.0.CO;2

Schauroth, C., and P. H. Becker. 2008. Post-fledging body mass increase in Common Terns Sterna hirundo: influence of age, sex and year. Ibis 150:50-58. https://doi.org/10.1111/j.1474-919X.2007.00735. $\mathrm{x}$

Sedinger, J. S. 1986. Growth and development of Canada Goose goslings. Condor 88:169-180. https://doi.org/10.2307/1368912
Seward, A., N. Ratcliffe, S. Newton, R. Caldow, D. Piec, P. Morrison, T. Cadwallender, W. Davies, and M. Bolton. 2019. Metapopulation dynamics of Roseate Terns: sources, sinks and implications for conservation management decisions. Journal of Animal Ecology 88:138-153. https://doi.org/10.1111/1365-2656.12904

Shealer, D. A., and J. Burger. 1995. Comparative foraging success between adult and one-year-old Roseate and Sandwich Terns. Colonial Waterbirds 18:93-99. https://doi.org/10.2307/1521403

Sorensen, M. C., J. M. Hipfner, T. K. Kyser, and D. R. Norris. 2009. Carry-over effects in a Pacific seabird: stable isotope evidence that pre-breeding diet quality influences reproductive success. Journal of Animal Ecology 78:460-467. https://doi. org/10.1111/j.1365-2656.2008.01492.x

Spendelow, J. A., J. E. Hines, J. D. Nichols, I. C. T. Nisbet, G. Cormons, H. Hays, J. J. Hatch, and C. S. Mostello. 2008. Temporal variation in adult survival rates of Roseate Terns during periods of increasing and declining populations. Waterbirds 31:309-319. https://doi.org/10.1675/1524-4695-31.3.309

Spendelow, J. A., J. D. Nichols, J. E. Hines, J.-D. Lebreton, and R. Pradel. 2002. Modelling postfledging survival and age-specific breeding probabilities in species with delayed maturity: a case study of Roseate Terns at Falkner Island, Connecticut. Journal of Applied Statistics 29:385-405. https://doi.org/10.1080/02664760120108764

Stenseth, N. C., and A. Mysterud. 2002. Climate, changing phenology, and other life history traits: nonlinearity and matchmismatch to the environment. Proceedings of the National Academy of Sciences of the United States of America 99:13379-13381. https://doi.org/10.1073/pnas.212519399

Stienen, E. W. M., and A. Brenninkmeijer. 2002. Variation in growth in Sandwich Tern chicks Sterna sandvicensis and the consequences for pre- and post-fledging mortality. Ibis 144:567-576. https://doi.org/10.1046/j.1474-919X.2002.00086.X

Szostek, K. L., and P. H. Becker. 2015. Survival and local recruitment are driven by environmental carry-over effects from the wintering area in a migratory seabird. Oecologia 178:643-657. https://doi.org/10.1007/s00442-015-3298-2

Tamarin-Brodsky, T., and Y. Kaspi. 2017. Enhanced poleward propagation of storms under climate change. Nature Geoscience 10:908-913. https://doi.org/10.1038/s41561-017-0001-8

Trull, P., S. Hecker, M. J. Watson, and I. C. T. Nisbet. 1999. Staging of Roseate Terns Sterna dougallii in the post-breeding period around Cape Cod, Massachusetts, USA. Atlantic Seabirds 1:145-158.

U.S. Department of Interior, Fish and Wildlife Service. 1987. 50 CFR Part 17. Endangered and threatened wildlife and plants; determination of endangered and threatened status for two populations of the roseate tern. Federal Register 52 (211):42064-42071.

Velando, A., and I. Munilla. 2011. Disturbance to a foraging seabird by sea-based tourism: implications for reserve management in marine protected areas. Biological Conservation 144:1167-1174. https://doi.org/10.1016/j.biocon.2011.01.004 
Warnock, N. 2010. Stopping vs. staging: the difference between a hop and a jump. Journal of Avian Biology 41:621-626. https://doi. org/10.1111/j.1600-048X.2010.05155.X

Watson, M. J., and J. J. Hatch. 1999. Differences in foraging performance between juvenile and adult Roseate Terns at a premigratory staging area. Waterbirds 22:463-465. https://doi. org/10.2307/1522125

Watson, M. J., J. A. Spendelow, and J. J. Hatch. 2012. Post-fledging brood and care division in the Roseate Tern (Sterna dougallii). Journal of Ethology 30:29-34. https://doi.org/10.1007/s10164-011-0286-9

White, G. C., and K. P. Burnham. 1999. Program MARK: survival estimation from populations of marked animals. Bird Study 46: S120-S139. https://doi.org/10.1080/00063659909477239

Wickham, H. 2009. ggplot2: elegant graphics for data analysis. Springer-Verlag, New York, New York, USA.

Williams, B. K., J. D. Nichols, and M. J. Conroy. 2002. Analysis and management of animal populations. Academic Press, New York, New York, USA. 
1 Appendix 1. Model rankings for Pradel parameterization for residency and recruitment of hatch-

2 year Roseate Terns during the 2014 and 2015 staging seasons at Cape Cod National Seashore,

3 MA. We fit a series of models for each parameter, beginning with the detection probability $(p)$

4 while we used the most general parameterization (fully year*region*week varying) for the other

5 model parameters ( $\Phi$ and $f$; Table A1.1). We repeated this model selection procedure using the

6 best-supported models from previous steps to fit models for the remaining parameters (residency

7 probability, $\Phi$; Table A1.2 and recruitment rate, $f$; Table A1.3). 
Table A1.1. Pradel survival and recruitment model rankings for $p$, detection probability. We constrained the time-varying detection

9 probabilities such that our first two and final two detection probabilities were equal (e.g., $p 1=p 2$ and $p 9=p 10$ ). We modeled the most

10 general parameterization (time * year * region) for the residency $(\Phi)$ and recruitment $(f)$ parameters and used the best-supported

11 model for detection probability $(p)$ from this model selection process in subsequent model selection steps for each of the remaining

12 parameters.

\begin{tabular}{|c|c|c|c|c|c|c|}
\hline Model $^{\dagger}$ & QAICc & $\triangle \mathrm{QAICc}$ & $w_{i}{ }^{\S}$ & Likelihood $^{\prime}$ & $\mathrm{K}^{\mathrm{TI}}$ & Deviance $^{\#}$ \\
\hline$\Phi($ time $*$ year $*$ region $) p($ time $*$ year + region $) f($ time $*$ year $*$ region $)$ & 7782.15 & 0 & 0.68 & 1 & 89 & 641.91 \\
\hline$\Phi($ time $*$ year $*$ region $) p($ region $) f($ time $*$ year $*$ region $)$ & 7785.13 & 2.98 & 0.15 & 0.23 & 74 & 676.03 \\
\hline$\Phi($ time $*$ year $*$ region $) p($ year $*$ region $) f($ time $*$ year $*$ region $)$ & 7785.65 & 3.50 & 0.12 & 0.17 & 76 & 672.41 \\
\hline$\Phi($ time $*$ year $*$ region $) p($ year + time + region $) f($ time $*$ year $*$ region $)$ & 7787.27 & 5.12 & 0.05 & 0.08 & 82 & 661.59 \\
\hline$\Phi($ time $*$ year $*$ region $) p($ time $*$ region $) f($ time $*$ year $*$ region $)$ & 7796.59 & 14.44 & 0 & 0 & 88 & 658.43 \\
\hline$\Phi($ time $*$ year $*$ region $) p($ time $*$ region + year $) f($ time $*$ year $*$ region $)$ & 7798.09 & 15.94 & 0 & 0 & 89 & 657.84 \\
\hline$\Phi($ time $*$ year $*$ region $) p($ time $*$ year $*$ region $) f($ time $*$ year $*$ region $)$ & 7802.39 & 20.24 & 0 & 0 & 104 & 630.8 \\
\hline$\Phi($ time $*$ year $*$ region $) p() f.($ time $*$ year $*$ region $)$ & 7806.62 & 24.47 & 0 & 0 & 73 & 699.59 \\
\hline$\Phi($ time $*$ year $*$ region $) p($ year $*$ time $) f($ time $*$ year $*$ region $)$ & 7807.23 & 25.08 & 0 & 0 & 88 & 669.07 \\
\hline$\Phi($ time $*$ year $*$ region $) p($ time $) f($ time $*$ year $*$ region $)$ & 7807.53 & 25.38 & 0 & 0 & 80 & 686.00 \\
\hline$\Phi\left(\right.$ time $^{*}$ year $*$ region $) p\left(\right.$ Time $\left.^{2}\right) f($ time $*$ year $*$ region $)$ & 7808.04 & 25.89 & 0 & 0 & 74 & 698.94 \\
\hline$\Phi($ time $*$ year $*$ region $) p($ Time $) f($ time $*$ year $*$ region $)$ & 7808.62 & 26.47 & 0 & 0 & 74 & 699.51 \\
\hline
\end{tabular}


$14{ }^{\dagger}$ Model parameterization, where $\Phi$ is the residency parameter, $p$ is the detection probability, and $f$ is the recruitment rate parameter.

15 Models tested included combinations of constant (.), week-varying (time), time trend (Time), quadratic time trend (Time ${ }^{2}$ ), year-

16 varying, and region-varying detection probabilities. We modeled the most general parameterization (time * year * region) for the

17 residency $(\Phi)$ and recruitment $(f)$ parameters.

18 Adjusted AICc values. A $\hat{c}$ value of 2.03 was applied to the dataset to correct for overdispersion of the data.

$19 \S$ QAICc model weight

$20 \quad$ Model likelihood

21 "Number of parameters included in the model

$22{ }^{\#}$ Model deviance 
Table A1.2. Pradel survival and recruitment model rankings for residency probability $(\Phi)$, using the best-supported model from our

24 previous model selection procedure for detection probability ( $p$; Table A1.1). We constrained the detection probability such that our

25 first two and final two detection probabilities were equal (e.g., $p 1=p 2$ and $p 9=p 10$ ) so that all parameters would be identifiable. We

26 modeled the most general parameterization (time * year * region) on the recruitment rate $(f)$ parameter in all models in this step.

\begin{tabular}{|c|c|c|c|c|c|c|}
\hline Model $^{\dagger}$ & QAICc & $\triangle \mathrm{QQAICc}$ & $w_{i}{ }^{\S}$ & Likelihood $^{\mid}$ & $\mathrm{K}^{\mathrm{TI}}$ & Deviance $^{\#}$ \\
\hline$\Phi\left(\right.$ Time $\left.^{2}\right) p($ time $*$ year + region $) f($ time $*$ year $*$ region $)$ & 7729.22 & 0 & 0.81 & 1.00 & 55 & 659.25 \\
\hline$\Phi($ Time $) p($ time $*$ year + region $) f($ time $*$ year $*$ region $)$ & 7732.17 & 2.96 & 0.18 & 0.23 & 55 & 662.21 \\
\hline$\Phi($ time $) p($ time $*$ year + region $) f($ time $*$ year $*$ region $)$ & 7739.79 & 10.57 & 0 & 0.01 & 62 & 655.44 \\
\hline$\Phi($ time + year + region $) p($ time $*$ year + region $) f($ time $*$ year $*$ region $)$ & 7743.89 & 14.68 & 0 & 0 & 64 & 655.43 \\
\hline$\Phi($ time $*$ region $) p($ time $*$ year + region $) f($ time $*$ year $*$ region $)$ & 7754.91 & 25.69 & 0 & 0 & 71 & 652.00 \\
\hline$\Phi($ time $*$ year + region $) p($ time $*$ year + region $) f($ time $*$ year $*$ region $)$ & 7755.30 & 26.09 & 0 & 0 & 72 & 650.34 \\
\hline$\Phi($ time $*$ region $) p($ time $*$ year + region $) f($ time $*$ year $*$ region $)$ & 7756.30 & 27.08 & 0 & 0 & 71 & 653.39 \\
\hline$\Phi($ time $*$ region + year $) p($ time $*$ year + region $) f($ time $*$ year $*$ region $)$ & 7758.29 & 29.07 & 0 & 0 & 72 & 653.32 \\
\hline$\Phi($ time $*$ year $*$ region $) p($ time $*$ year + region $) f($ time $*$ year $*$ region $)$ & 7782.15 & 52.94 & 0 & 0 & 89 & 641.91 \\
\hline$\Phi() p.($ time $*$ year + region $) f($ time $*$ year $*$ region $)$ & 7801.05 & 71.84 & 0 & 0 & 54 & 733.14 \\
\hline$\Phi($ region $) p($ time $*$ year + region $) f($ time $*$ year $*$ region $)$ & 7802.37 & 73.16 & 0 & 0 & 55 & 732.41 \\
\hline$\Phi($ year $) p($ time $*$ year + region $) f($ time $*$ year $*$ region $)$ & 7802.40 & 73.19 & 0 & 0 & 55 & 732.44 \\
\hline$\Phi($ year $*$ region $) p($ time $*$ year + region $) f($ time $*$ year $*$ region $)$ & 7805.51 & 76.29 & 0 & 0 & 57 & 731.44 \\
\hline
\end{tabular}


$28{ }^{\dagger}$ Model parameterization, where $\Phi$ is the residency probability, $p$ is the detection probability, and $f$ is recruitment rate. Models tested

29 included combinations of constant (.), week-varying (time), time trend (Time), quadratic time trend (Time ${ }^{2}$ ), year-varying, and region-

30 varying $\Phi$ probabilities. We used the best model from the detection probability model selection procedure, fully time-by-year-by-

31 region varying $p$, and we modeled the most general parameterization (time * year * region) on the recruitment rate $(f)$ parameter in all

32 models in this step.

$33 \quad$ Adjusted AICc values. A $\hat{c}$ value of 2.03 was applied to the dataset to correct for overdispersion of the data.

34 \$QAICc model weight

$35 \mid$ Model likelihood

$36{ }^{\mathbb{I}}$ Number of parameters included in the model

$37 \quad$ \#odel deviance 
39 Table A1.3. Pradel survival and recruitment model rankings for recruitment rate $(f)$, using the best-supported model from our previous

40 model selection procedure for detection probability ( $p$; Table A1.1) and the two best-supported models for residency probability ( $\Phi$;

41 Table A1.2). We constrained the detection probability such that our first two and final two detection probabilities were equal (e.g.,

$42 p 1=p 2$ and $p 9=p 10)$ so that all parameters would be identifiable.

\begin{tabular}{|c|c|c|c|c|c|c|}
\hline Model $^{\dagger}$ & QAICc & $\triangle \mathrm{QQAICc}$ & $w_{i}{ }^{\S}$ & Likelihood $^{\mid}$ & $\mathrm{K}^{\mathrm{II}}$ & Deviance $^{\#}$ \\
\hline$\Phi\left(\right.$ Time $\left.^{2}\right) p($ time $*$ year + region $) f($ time + year + region $)$ & 7726.88 & 0 & 0.51 & 1.00 & 30 & 707.90 \\
\hline$\Phi\left(\right.$ Time $\left.^{2}\right) p($ time $*$ year + region $) f($ time $*$ year $*$ region $)$ & 7729.22 & 2.33 & 0.16 & 0.31 & 55 & 659.25 \\
\hline$\Phi\left(\right.$ Time $\left.^{2}\right) p($ time $*$ year + region $) f($ time $*$ region + year $)$ & 7729.77 & 2.88 & 0.12 & 0.24 & 38 & 694.53 \\
\hline$\Phi($ Time $) p($ time $*$ year + region $) f($ time + year + region $)$ & 7729.94 & 3.06 & 0.11 & 0.22 & 30 & 710.95 \\
\hline$\Phi($ Time $) p($ time $*$ year + region $) f($ time $*$ year $*$ region $)$ & 7732.17 & 5.29 & 0.04 & 0.07 & 55 & 662.21 \\
\hline$\Phi($ Time $) p($ time $*$ year + region $) f($ time $*$ region + year $)$ & 7732.47 & 5.59 & 0.03 & 0.06 & 38 & 697.23 \\
\hline$\Phi\left(\right.$ Time $\left.^{2}\right) p($ time $*$ year + region $) f($ time $*$ region $)$ & 7733.78 & 6.89 & 0.02 & 0.03 & 37 & 700.57 \\
\hline$\Phi\left(\right.$ Time $\left.^{2}\right) p($ time $*$ year + region $) f($ time $*$ year + region $)$ & 7736.04 & 9.15 & 0.01 & 0.01 & 38 & 700.80 \\
\hline$\Phi($ Time $) p($ time $*$ year + region $) f($ time $*$ region $)$ & 7737.08 & 10.2 & 0 & 0.01 & 37 & 703.88 \\
\hline$\Phi($ Time $) p($ time $*$ year + region $) f($ time $*$ year + region $)$ & 7739.13 & 12.25 & 0 & 0 & 38 & 703.89 \\
\hline$\Phi\left(\right.$ Time $\left.^{2}\right) p($ time $*$ year + region $) f($ Time $)$ & 7739.83 & 12.95 & 0 & 0 & 21 & 739.06 \\
\hline$\Phi\left(\right.$ Time $\left.^{2}\right) p($ time $*$ year + region $) f($ time $)$ & 7739.92 & 13.03 & 0 & 0 & 28 & 724.99 \\
\hline$\Phi($ Time $) p($ time $*$ year + region $) f($ time $)$ & 7742.31 & 15.43 & 0 & 0 & 28 & 727.38 \\
\hline
\end{tabular}




\begin{tabular}{|c|c|c|c|c|c|c|}
\hline$\Phi($ Time $) p($ time $*$ year + region $) f($ Time $)$ & 7742.74 & 15.86 & 0 & 0 & 21 & 741.97 \\
\hline$\Phi\left(\right.$ Time $\left.^{2}\right) p($ time $*$ year + region $) f($ time $*$ year $)$ & 7748.27 & 21.39 & 0 & 0 & 37 & 715.07 \\
\hline$\Phi($ Time $) p($ time $*$ year + region $) f($ time $*$ year $)$ & 7751.02 & 24.13 & 0 & 0 & 37 & 717.82 \\
\hline$\Phi\left(\right.$ Time $\left.^{2}\right) p($ time $*$ year + region $) f\left(\right.$ Time $\left.^{2}\right)$ & 7774.61 & 47.73 & 0 & 0 & 21 & 773.84 \\
\hline$\Phi($ Time $) p($ time $*$ year + region $) f\left(\right.$ Time $\left.^{2}\right)$ & 7777.51 & 50.62 & 0 & 0 & 21 & 776.73 \\
\hline$\Phi($ Time $) p($ time $*$ year + region $) f($ year $*$ region $)$ & 7843.23 & 116.35 & 0 & 0 & 23 & 838.42 \\
\hline$\Phi\left(\right.$ Time $\left.^{2}\right) p($ time $*$ year + region $) f($ year $*$ region $)$ & 7845.96 & 119.08 & 0 & 0 & 23 & 841.15 \\
\hline$\Phi($ Time $) p($ time $*$ year + region $) f($ region $)$ & 7848.94 & 122.06 & 0 & 0 & 21 & 848.17 \\
\hline$\Phi($ Time $) p($ time $*$ year + region $) f()$. & 7850.15 & 123.27 & 0 & 0 & 20 & 851.40 \\
\hline$\Phi\left(\right.$ Time $\left.^{2}\right) p($ time $*$ year + region $) f($ region $)$ & 7851.55 & 124.67 & 0 & 0 & 21 & 850.78 \\
\hline$\Phi($ Time $) p($ time $*$ year + region $) f($ year $)$ & 7852.12 & 125.24 & 0 & 0 & 21 & 851.35 \\
\hline$\Phi\left(\right.$ Time $\left.^{2}\right) p($ time $*$ year + region $) f()$. & 7852.85 & 125.97 & 0 & 0 & 20 & 854.10 \\
\hline$\Phi\left(\right.$ Time $\left.^{2}\right) p($ time $*$ year + region $) f($ year $)$ & 7854.71 & 127.82 & 0 & 0 & 21 & 853.93 \\
\hline
\end{tabular}

$44{ }^{\dagger}$ Model parameterization, where $\Phi$ is the residency probability, $p$ is the detection probability, and $f$ is recruitment rate. Models tested

45 included combinations of constant (.), week-varying (time), time trend (Time), quadratic time trend (Time ${ }^{2}$ ), year-varying, and region-

46 varying $\Phi$ probabilities. We used the best model from the detection probability model selection procedure, fully time-by-year-by-

47 region varying $p$, and we used the two best-supported model from the residency probability model selection procedure (Time- and

48 Time ${ }^{2}$-varying $\left.\Phi\right)$ to fit models for $f$. 
$49 \$$ Adjusted AICc values. A $\hat{c}$ value of 2.03 was applied to the dataset to correct for overdispersion of the data.

50 \$QAICc model weight

$51 \quad$ Model likelihood

52 IINumber of parameters included in the model

53 \#Model deviance 